ANDRZEJ RACZYK

University of Wroctaw, Poland

\title{
One Company - Many Worlds. Activity Diversification within Business Entities: the Example of Dolnośląskie Voivodeship
}

\begin{abstract}
One of the significant problems related to business entities is the implementation of a number of different types of activity by individual companies. This issue, despite being relatively well researched among individual or groups of businesses has yet to be studied comprehensively. This is due to the fact that the vast majority of studies focus only on the predominant type of activity declared at the time of company registration. The objective of this research was to identify regularities in the number and structure of activity types within individual business entities in Dolnośląskie Voivodeship. The survey covered all entities actively operating in the region - almost 176000 in total. The study examined all types of activity carried out (according to PKD 2007 including the subclass level) as well as their location (by gmina). The research was based on data from the Central Register and Information on Economic Activity. The study showed that the population is dominated by those conducting many different activities - about 8.2 per company on average. The inclusion of all (and not just dominant) activities affects the observed economic structures, including the spatial dimension.
\end{abstract}

Keywords: business entities; economic activities; Dolnośląskie Voivodeship; internal diversification

Received: 25 October 2019

Accepted: 20 April 2020

\section{Suggested citation:}

Raczyk, A. (2020). One Company - Many Worlds. Activity Diversification within Business Entities: the Example of Dolnośląskie Voivodeship. Przedsiębiorczość - Edukacja [Entrepreneurship Education], 16(1), 290-301. doi: 10.24917/20833296.161.23

\section{Introduction}

The issue of diversifying the activity of business entities is an essential subject of multidisciplinary research (Pitts, Hopkins, 1982; Ramanujam, Varadarajan, 1989). This issue, although relatively well known due to research on individual companies (or selected groups of companies), has not resulted in a comprehensive approach. This is mainly due to the objective difficulties of measuring this phenomenon. In the literature, a dichotomy can be found: either taking into account the internal diversification of companies or the 
assumption that they are internally undifferentiated. In the latter case, this is related to the assumption that the predominant type of activity (most often declared at the time of company registration) fully represents the company's activity profile. For pragmatic reasons, this approach dominates in academic and in public research (e.g. by the Central Statistical Office in Poland, or Eurostat in the EU). However, there are very few studies trying to compare both approaches on an empirical basis. This paper tries to bridge this gap. Its objective is to check whether and to what extent it is justified to take into account internal diversification in terms of business, and how the adoption of such a perspective may affect the results of an analysis.

\section{The aim, scope of work and research method}

The purpose of the research is to identify regularities in the number and type of activity within all economic entities operating in the area of Dolnośląskie Voivodeship, from the position of individual businesses. The survey covered economic entities actively operating in the region - in total almost 176000 . The activities taken into account included all those carried out according to the Polish Classification of Activities (Polska Klasyfikacja Działalności, PKD) 2007, including the subclass level, as well as their location (by gmina corresponding to the LAU level 2). The basis was data from the Central Register and Information on Economic Activity (CEiIoDG), as of the end of 2018. This database operates on the basis of the act of 2018 on the Central Register and Information on Economic Activity and the Information Point for the Entrepreneur (Journal of Laws 2018 item 647). This is mandatory when starting a business in Poland for all entities conducting a business activity, except for those unregistered. It can, therefore, be assumed that it is comprehensive. In contrast to the REGON database, often used in Polish conditions and maintained by the Central Statistical Office (Środa-Murawska, Szymańska, 2013), CEiIoDG enables a full and easy on-line updating of the information reported by entrepreneurs. However, without separate research, it cannot be determined whether such an update is actually carried out by entrepreneurs in the event of relevant changes in their companies and, as a consequence, whether it fully reflects reality. However, it seems that considering key information (e.g. suspension or cessation of operations) it is more reliable than the REGON register, which is characterised by a significant over-representation of the entities listed (see Raczyk, 2009).

Originally, there were a total of 373000 business entities in the CEiIoDG database for the studied area but only active entities with the required information were included. As a result, entities not operating, with suspended operations or with no other activities were removed from further analysis. As a result, the survey eventually covered 175963 business entities. Implementation was associated with a very laborious and time-consuming procedure for processing the database because the information was found in a single variable. As a result, a lot of entries had to be disentangled. Due to the size of the databases, it was impossible to carry out analyses nationwide based on the available hardware and software resources.

The research area adopted for the study was the Lower Silesia region, which is identified with Dolnośląskie Voivodeship. This choice resulted from the fact that it is one of the most dynamically developing regions of Poland, both economically (Churski, 2014) and entrepreneurially (Sołtys, Dorocki, 2016). At the same time, it has a fairly large range 
of intra-regional differences measured by overall levels of development (Raczyk, 2010), as well as areas of stagnation and of growth (Churski, 2014). At the same time, it is clearly functionally diverse. It includes, among others, the Wrocław metropolitan area, industrial areas (e.g. Legnica-Głogów Copper District), mountainous areas (Sudeten) as well as agricultural, forestry, crossborder etc. areas. As a result, it makes it possible to take into account a number of different conditions. Due to the number of businesses (in 169 gminas), the research area allows relevant statistical analyses.

\section{Theoretical aspects of diversifying the activities of business entities}

Enterprises and organisations, treated as complex and adaptive systems, can be viewed from two fundamentally different perspectives: the functional perspective (black-box) and the structural perspective (white-box) (Hoogervorst, 2004). The first focuses on issues of the company's operation as a whole, including behaviour, performance, availability, resilience, efficiency and performance. The latter focuses on exploring its internal operations, including structures, management and diversification. What seems particularly important is that both the functional and structural perspectives are very often associated with fundamentally different concepts and language in describing companies (Hoogervorst, 2004). Therefore, the research usually falls under either one or the other approach, and empirical studies confronting the results of both are relatively few.

As M. Gorynia (2012) indicates, the approach used in research is also the result of adopting a specific theory of the enterprise as a starting point for the analyses. Neoclassical theories treat companies as businesses whose activity can be reduced to processing input streams (such as raw materials, other materials, labour, external services) into output streams (such as goods, services, waste, etc.). In this approach, processes within the company are irrelevant. Therefore, the internal diversity of its activity is also irrelevant. In turn, managerial and behavioural theories, or those connected with the new institutional economics, more or less take into account the issue of internal company differentiation.

It should be noted that very often the way of collecting and sharing data imposes the adoption of a specific perspective. It may cause, in research practice, a lack of proper reflection on its appropriateness and a critical approach to the outcomes obtained as a result of its application. It is interesting in this context to find out to what extent the choice of research perspective is the result of an informed decision, and to what extent it is determined by the availability of data.

Research devoted to the diversification of company activities indicates two main ways of implementing this diversification (Rosa, Scott, 1999):

- by establishing new companies,

- by expanding the business profile within existing companies.

Both trends are widely represented in the literature. The phenomenon of diversification is assessed very differently and can be associated with both positive and negative effects. In this context, P. Rosa and M. Scott (1999) indicate that the largest source of new fast-growing enterprises is entrepreneurs with existing enterprises and not beginners. Diversification can also bring measurable benefits for farms (Clark, 2009), and for large companies within high concentrated industries as it may stimulate competition (Berry, 1975). Besides, B. Jovanovic and R.J. Gilbert (1993) note that diversified companies 
achieve far more significant benefits from R \& D because they can adapt and transfer innovation between the various activities they conduct.

In turn, Peters and Waterman (1982) take a different position, emphasising that from a business perspective, a better strategy is to focus on one, dominant activity rather than on its diversification. On the other hand, at the macroeconomic level, excessive diversification of the activities of large entities (e.g. multinational corporations) leads to a weakening of the development processes (Rosa, Scott, 1999).

As R.A. Pitts (1982) notes, virtually every company conducts functionally diverse activities. In this case, the problem is not so much whether they occur, but what methods can be used to identify them objectively. In this case, there are three principal approaches (Pitts, 1982):

- based on resources used by enterprises (supplies),

- based on the markets in which they operate,

- based on the goods and services they offer. In this context, each product may indicate a separate activity.

In Ch.H. Berry's (1975) approach, diversification means an increase in the number of sectors in which companies operate. This approach was used in this study.

One of the more complete lists of potential motives for diversification of companies was made by Jovanovic and Gilbert (1993). They pointed to the following:

- risk reduction - liquidation of one activity does not mean the collapse of the entire company,

- greater access to funds, e.g. through the transfer of funds from one activity to another if it provides a higher rate of return,

- compatibility of offered products - the company can better meet the needs of customers by providing not one, but a set of related products (e.g. consumer electronics),

- improving performance, e.g. thanks to a joint promotion, advertising or distribution for different products,

- gaining market advantage - one company with a significant market share of two substitution products achieves greater benefits than two separate and competing businesses selling the same products,

- achieving managerial goals, e.g. running several activities at once reduces the ability of shareholders to control the effectiveness of managerial activities.

Regardless of the observed increase in the number of articles indicating the legitimacy of using a structural perspective (white-box) for the study of economic entities, the vast majority related to spatial analysis (i.e. socio-economic geography and spatial management) is based on a functional approach (black-box). This is mainly due to the method of collecting data from official statistics, and suitable formal and legal solutions (including, for example, existing business registers). In particular, this affects approaches associated with research on various aspects of entrepreneurship (e.g. Kamińska, 2006; Jasiniak, 2013; Markowicz, 2016; Śleszyński, 2006), economic structures (e.g. Ilnicki, 2009; Kamińska, 2006; Rachwał, 2013), selected activities including those associated with technological development (incl. Namyślak, 2013; Stryjakiewicz, 2009) or the business environment (incl. Dominiak, 2006), and functional and spatial structures (incl. Bałach-Frankiewicz, Ciok, Ilnicki, 2016; Dziewoński, 1971; Jerczyński, 1977; Szafrańska, 2002). Equally important is the fact that this has an impact on public policies, including development policies implemented at national, regional and local levels (e.g. industrial policies, innovation development, clusters, etc.). 
According to the provisions in force in Poland, the basis for classifying a given business to a particular level of the PKD classification is its principal activity (Journal of Laws of 2007, no. 251, item 1885). It is defined as the activity with the largest share (e.g. measured by value-added, gross production, sales value, employment, remuneration) characterising the entity's operations. The dominant activity declared cannot be changed more than once every two years.

The choices made are apparent from statistical surveys, however, they are associated with several controversial assumptions. First, the activity reported at the time of registration as dominant does not always remain so, and the information update system probably does not work effectively. As indicated by A. Raczyk's research (2010) conducted on the example of the institutional space of the town of Milicz (and taking into account all economic entities, i.e. over 1500 businesses), as many as $26 \%$ had a different (compared to declared in the register) activity profile measured on the PKD group level. Besides, concerning the small and medium-sized enterprises sector, which is very mobile regarding its activity and flexibly adapted to current demand, the concept of a dominant business is irrelevant. It is a subject to constant change which, due to time constraints (once every two years), cannot even be recorded in the register.

Secondly, it should be borne in mind that the activity defined as predominant in a situation where a company conducts several different activities may in practice constitute a small share of its total business (much less than 50\%). In this case, it is predominant only by name. As a result, such an approach necessarily omits other activities that together have a dominant position or relate to fundamental aspects for the functioning of the company (as well as for the entire economy) - including innovative and creative activities.

Thirdly, the predominant activity may be dictated by the ad hoc benefits of existing legislation, e.g. the desire to circumvent the Sunday trading ban, a wish to apply for financial support from various types of public programs or to participate in tenders, etc.

Fourthly, it should be emphasised that the very choice of a dominant activity is highly subjective. The problem may be, for example, a difficulty in resolving this issue unequivocally when individual indicators (e.g. production, employment, sales) suggest other activities. Besides, in some cases, especially with newly emerging businesses, such a choice is a projection of the directions of the future development of the company, which does not always materialise.

The application of the structural approach adopted here consists of examining all (and not just the dominant) activities of business entities. In this case, the main problem is to determine the importance of activities occurring within individual businesses. Knowing their actual proportions would require, however, individual examination of all companies, which due to the statistical population is very difficult to implement (if indeed possible). The solution to this problem seems to be to assign individual activities proportions so that their sum within the business entity is 1 (e.g. in the case of two activities in the company, each receives 0.5 , for three -0.33 , etc.). In the following, such proportions were defined as a "weighted share of activities". This approach requires the assumption that all activities entered in the business register are carried out in the same dimension, which of course is a significant simplification. However, this makes it possible to include all the activities in the study. The remaining part of this article summarises the results obtained based on both functional and structural approaches taking into account these circumstances. 


\section{Functional and structural perspectives: results of empirical research}

As a result of research carried out within the 176000 companies, over 1.4 million activities were identified which means that adopting a functional perspective omits over 1.2 million. The average number per company was 8.2 , and the maximum in one entity 606 (out of 654 of all subclasses listed in the PKD system). It seems that in some cases a considerable number of activities were the result of their being declared "just in case", e.g. in about $4 \%$ of companies with more than 30 activities. A group of companies carrying out only one activity covered $28 \%$ of entities - only within this subpopulation did the structural and functional approaches not lead to differences in the test results. It should be noted that, according to the previous assumption, if a proportional division of individual activities within an entity is made, then the activity defined as dominant in about $28 \%$ has a $100 \%$ share, in about $9 \%$ - half, and others - below $30 \%$ (Figure 1). In many cases, this value is highly insignificant.

Adopting a functional perspective based on prevailing activities also results in a higher concentration of economic structures than a reference to a structural perspective based on weighted activities. In the first case, 49 activity subclasses (7.5\% of all subclasses) were classified as nonexistent.

It is essential to decide to what extent the adoption of a specific research perspective affects the results of the research obtained. First of all, to what extent does it differentiate observed economic structures? In general, across the entire region, the similarity indicators for structures (Chomątowski, Sokołowski, 1978) measured by prevailing and

Figure 1. Graph of the share of the prevailing activity in economic entities in Dolnośląskie Voivodeship, including all activities and assuming equal weightings: 2018 (\%)

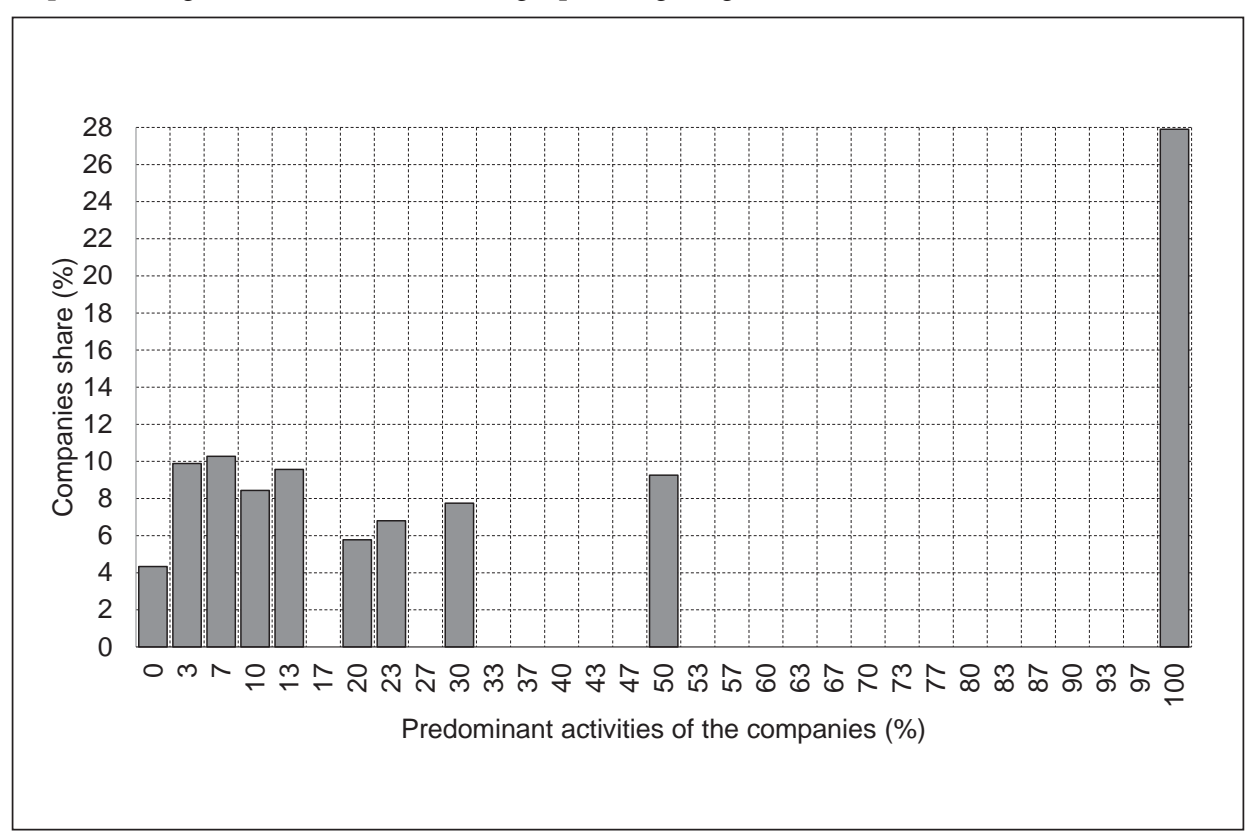

Source: author 
weighted activities were relatively high and ranged from almost $95 \%$ at the section level to over $82 \%$ at the department level (Table 1). It should be noted, however, that this was primarily conditioned by the imperfection of the method taking into account only the overall balance of changes. The result is that it does not show the actual scale of transformations, in particular when economic entities are also differentiated by additional information, e.g. about the number of employees, value-added, sales, location, date of creation, etc. Accurate determination of the scale of differences resulting from the adoption of both research perspectives, therefore, requires taking into account the changes taking place at the level of individual companies.

Table 1. Economic structures based on the functional and structural approaches in Dolnośląskie Voivodeship: end of 2018 (\%)

\begin{tabular}{|l|c|}
\hline \multicolumn{1}{|c|}{ PKD 2007 } & $\begin{array}{c}\text { Similarity index of structures measured } \\
\text { by both prevailing and weighted activities }\end{array}$ \\
\hline Class & 82.3 \\
\hline Group & 86.6 \\
\hline Division & 90.1 \\
\hline Section & 94.9 \\
\hline
\end{tabular}

Source: author

In the studied population of companies, the average share of the prevailing activity in the total number within individual business entities, calculated from a structural approach at the level of PKD 2007, was 75\%, and at the level of departments - 50\%. The companies with more than one activity (multi-profile) recorded a decrease down to 50\% and 33\%, respectively. This indicates a relatively large scale of change in observed enterprise structures even at the highest levels of aggregation (i.e. sections, divisions), and the range of changes at lower levels (groups, classes, subclasses) could in some cases modify the results obtained. This observation is particularly important for research in which more moderate levels of aggregation are the basis for identifying several phenomena, including creative sectors (subclasses) (e.g. Namyślak, 2013), advanced technology industries (departments) (e.g. Gierańczyk, Rachwał, 2012), services according to R \& D intensity (divisions) (incl. Raczyk, Dobrowolska-Kaniewska, 2009). In the case of, for example, creativity, the proportion of companies engaged solely in creative activity was $1.7 \%$ in Dolnośląskie; conducting at least one (regardless of participation) creative activity $-27.1 \%$; and the proportion of weighted creative activities was $7.4 \%$. As a consequence, adopting a specific perspective fundamentally changed the possibilities and manner of inference, as it de facto concerned different dimensions. Similarly, differences were observed, e.g. when analysing the industry and services sectors according to technology levels.

Adopting a specific perspective also affects the occurrence of significant differences in the importance of several activities in the economic structure (Table 2). The scale of these differences is sometimes vast and causes substantial shifts in the business hierarchy. It may be due to the following conditions:

- the semantic capacity of specific categories, which translates into their frequent indication as prevailing activities, e.g. construction work related to the erection of buildings, activities related to software, retail sales in non-specialised stores, maintenance and repair of motor vehicles, 
- the typically ancillary or secondary nature of some categories, as a result of which they are underestimated in the functional approach (e.g. retail sales outside the store network, painting and glazing) although they occur relatively often.

Table 2. Activities with the most significant differences in structure based on the functional and structural approaches in Dolnośląskie Voivodeship: end of 2018 (in percentage points)

\begin{tabular}{|l|c|c|c|}
\hline \multirow{2}{*}{\multicolumn{1}{|c|}{ Activity type }} & \multicolumn{2}{c|}{$\begin{array}{c}\text { Subclass share } \\
\text { measured by activity (\%) }\end{array}$} & \multirow{2}{*}{$\begin{array}{c}\text { Difference } \\
\text { (p.p.) }\end{array}$} \\
\cline { 2 - 3 } & dominating & weighted & \\
\hline Construction work for buildings & 2.9 & 1.5 & 1.4 \\
\hline Software activities & 2.2 & 0.9 & 1.3 \\
\hline Retail sale in non-specialised stores & 2.4 & 1.2 & 1.2 \\
\hline Other retail sales outside the store network & $\mathbf{1 . 0}$ & $\mathbf{2 . 1}$ & $\mathbf{- 1 . 1}$ \\
\hline Maintenance and repair of motor vehicles & 2.8 & 1.8 & 1.0 \\
\hline Painting and glazing & $\mathbf{0 . 4}$ & $\mathbf{1 . 1}$ & $\mathbf{- 0 . 8}$ \\
\hline Engineering activities & 2.0 & 1.2 & 0.8 \\
\hline Hairdressing and other beauty treatments & 3.0 & 2.3 & 0.7 \\
\hline $\begin{array}{l}\text { Accounting and bookkeeping activities; } \\
\text { tax consultancy }\end{array}$ & 1.8 & 1.1 & 0.7 \\
\hline $\begin{array}{l}\text { Restaurants and other permanent catering } \\
\text { establishments }\end{array}$ & 1.6 & 0.9 & 0.7 \\
\hline Road freight transport & 3.6 & 3.0 & 0.6 \\
\hline Other business consulting & 1.7 & 1.2 & 0.6 \\
\hline
\end{tabular}

Source: author's compilation

The study also examines spatial variations determined from both perspectives. It should be noted that the entrepreneurship indicators measured by the number of companies and the number of activities per capita by gmina are quite similar (Figure 2). However, the scale is quite different, confirmed by the relatively high and statistically significant correlation coefficient $(+0.854)$. To a large extent, they reflect the general level of socio-economic development of individual territorial systems. According to previous observations, however, considerable differences occur when researching a selected subpopulation of companies (including individual activities or groups). The study showed no statistically significant relationship between either examined indicator and the population. The size of a territorial unit is not a factor that differentiates either the formation of companies or their propensity to diversify.

On the other hand, the spatial variations in the average number of activities per economic entity are fundamentally different (Figure 2). It is difficult to indicate a single factor conditioning this but it can be seen, however, that they are partly related to the presence of functional areas (including suburbs) in the largest cities in the region, i.e. Wrockaw (e.g. Kobierzyce, Długołęka, Wisznia Mała, Kąty Wrocławskie), Jelenia Góra (Janowice Wielkie, Mysłakowice, Stara Kamienica) or Legnica (Krotoszyce). This may suggest that the spatial systems around the core create conditions for more diversified economic activity (at least in the statistical dimension), involving the use of various development impulses generated by the core areas. However, final verification of this hypothesis would require separate research. 
Figure 2. The number of activities per 100 inhabitants (A) and the average number of activities per economic entity (B) in Dolnośląskie Voivodeship: end of 2018
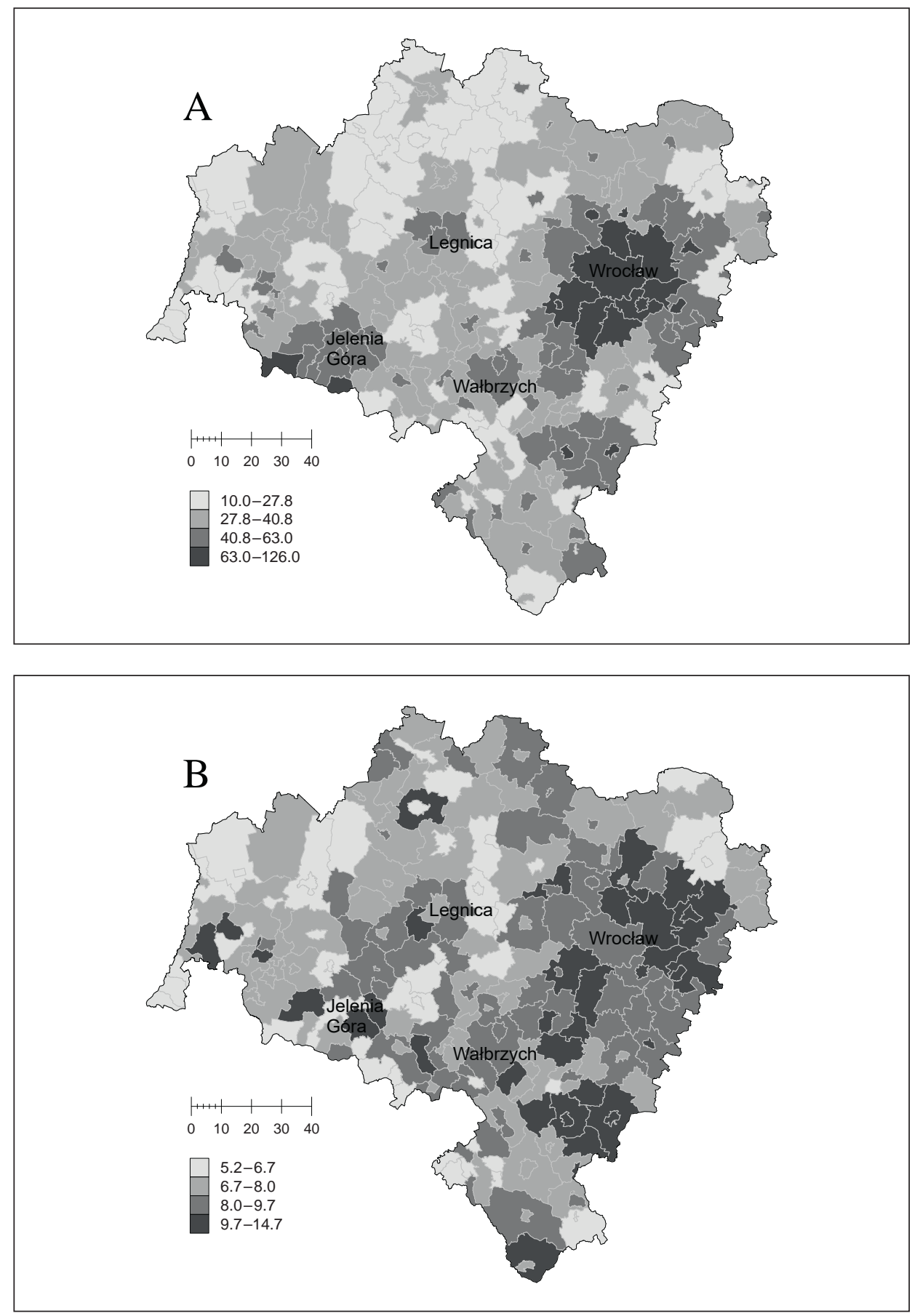

Source: author 


\section{Conclusions}

The work shows that the adoption of a functional or a structural perspective for research into business entities, including entrepreneurship, is essential for the results to be obtained. It significantly affects economic structures in which reference is to the activities carried out by individual companies (e.g. creativity, innovation). The scale of the differences found depends primarily on the level of aggregation of the data taken into account, with the largest at the subclass level and the smallest at the section level.

Of course, it should be borne in mind that in terms of access to information collected mainly from a functional point of view (e.g. as part of official statistics), most of the research will necessarily fit into the functional approach. However, there should be an awareness of the limitations associated with it and a critical approach taken to the results obtained. Besides, if possible, research that is based on other sources should be sought. From this point of view, a field inventory of companies is better than the use of data from public registers.

Regardless of this, taking into account a structural perspective creates excellent opportunities to study entrepreneurship or to shape economic structures. For example, in the field of the evolution of the business profile of companies over time, business strategy (single versus multi-profile), the survival rate of newly established single and multi-profile companies, their efficiency, and the shaping of functional and spatial structures related to single- and multi-profile activities, etc. It is also part of the discussion about the essence of entrepreneurship and the similar issue of whether an entrepreneur running a multi-profile company is more entrepreneurial than an entrepreneur running a company with a single activity.

In this context, it also seems necessary to emphasise several research problems when including all activities carried out by economic entities. These are the issues associated with difficulties in obtaining and processing relevant data and the need to have advanced hardware and software facilities.

\section{References}

Bałach-Frankiewicz, J., Ciok, S., Ilnicki, D. (2016). Struktura funkcjonalno-przestrzenna lokalnego zespołu osadnicza-produkcyjnego Jelcza-Laskowic. Rozprawy Naukowe IGiRR Uniwersytetu Wrocławskiego, 39.

Berry, Ch.H. (1975). Corporate growth and diversification. New Jersey: Princeton University Press.

Chomątowski, S., Sokołowski, A. (1978). Taksonomia struktur. Przegląd Statystyczny, 25(2), 217-226.

Churski, P. (2014). Variations in the spatial distribution of areas of economic growth and stagnation in Poland: Determinants and consequences. Quaestiones Geographicae, 33(2), 63-77.

Dominiak, J. (2006). Struktura i organizacja przestrzenna otoczenia biznesu w aglomeracji poznańskiej. Poznań: Bogucki Wydawnictwo Naukowe.

Dziewoński, K. (1971). Baza ekonomiczna i struktura funkcjonalna miast. Studium rozwoju pojęć, metod i ich zastosowań. Prace Geograficzne IG PAN, 87, 3-110.

Gierańczyk, W., Rachwał, T. (2012). Structural changes in the industry of Poland against the background of eastern European Union states. Quaestiones Geographicae, 31(2), 83-93.

Gort, M. (1962). Diversification and Integration in American Industry. New Jersey: Princeton University Press.

Gorynia, M. (2007). Studia nad transformacją i internacjonalizacją gospodarki polskiej. Warszawa: Difin. 
Hoogervorst, J. (2004). Enterprise architecture: Enabling integration, agility and change. International Journal of Cooperative Information Systems, 13(03), 213-233.

Ilnicki, D. (2009). Przestrzenne zróżnicowanie poziomu rozwoju usług w Polsce. teoretyczne i praktyczne uwarunkowania badań. Rozprawy Naukowe IGiRR Uniwersytetu Wrocławskiego, 11.

Jasiniak, M. (2013). Przedsiębiorstwa krajowe i zagraniczne w Polsce. Warunki i efekty działania. Łódź: Wydawnictwo Uniwersytetu Łódzkiego.

Jerczyński, M. (1977). Funkcje i typy funkcjonalne polskich miast. W: K. Dziewoński, M. Jerczyński (red.), Statystyczna charakterystyka miast. Funkcje dominujace. Statystyka Polski. Warszawa: GUS, 20-53.

Jovanovic, B., Gilbert, R.J. (1993). The Diversification of Production. Brookings Papers on Economic Activity. Microeconomics, 1, 197-247.

Kamińska, W. (2006). Pozarolnicza indywidualna działalność gospodarcza w Polsce latach 1989-2003. Warszawa: IGiPZ PAN.

Clark, J. (2009). Entrepreneurship and diversification on English farms: Identifying business enterprise characteristics and change processes. Entrepreneurship and Regional Development, 21(2), 213-236.

Markowicz, I. (2016). Tablice trwania firm w województwie zachodniopomorskim według rodzaju działalności. Prace Naukowe Uniwersytetu Ekonomicznego we Wrocławiu, 426, 108-117.

Namyślak, B. (2013). Działalności twórcze a rozwój miast. Przykład Wrocławia. Wrocław: Rozprawy Naukowe IGiRR Uniwersytetu Wrocławskiego, 30.

Pitts, R.A., Hopkins, H.D. (1982). Firm Diversity: Conceptualization and Measurement. Academy of Management Review, 7(4), 620-629.

Rachwał, T. (2013). Rola przedsiębiorstw przemysłowych w rozwoju gospodarki opartej na wiedzy. Prace Komisji Geografii Przemystu Polskiego Towarzystwa Geograficznego, 21, 189-211.

Raczyk, A. (2009). Metody badania przedsiębiorczości w oparciu o rejestr podmiotów gospodarki narodowej. Przedsiębiorczość - Edukacja [Entrepreneurship - Education], 5, 133-146.

Raczyk, A. (2010). Zróżnicowania wewnątrzregionalne w Polsce a polityka spójności: ujęcie dynamiczne. Prace Naukowe Uniwersytetu Ekonomicznego we Wrocławiu, 95, 52-65.

Raczyk, A., Dobrowolska-Kaniewska, H. (2009). Kształtowanie struktur przestrzennych sektora przemysłu i usług według poziomów techniki na przykładzie województwa dolnośląskiego. Prace Komisji Geografii Przemysłu Polskiego Towarzystwa Geograficznego, 13, 42-55.

Ramanujam, V., Varadarajan, P. (1989). Research on Corporate Diversification: A Synthesis. Strategic Management Journal, 10(6), 523-551.

Rosa, P., Scott, M. (1999). Entrepreneurial diversification, business-cluster formation, and growth. Environment and Planning C: Government and Policy, 17(5), 527-547.

Rozporządzenie Rady Ministrów z dnia 24 grudnia 2007 r. w sprawie Polskiej Klasyfikacji Działalności (PKD). Dz.U. $2007 \mathrm{nr} 251$ poz. 1885.

Śleszyński, P. (2006). Przedsiębiorstwa w przestrzeni Warszawy. Warszawa: PAN IGiPZ.

Sołtys, J., Dorocki, S. (2016). Wskaźnik przedsiębiorczości w jednostkach terytorialnych Polski zróżnicowanie w czasie i przestrzeni. Przedsiębiorczość - Edukacja [Entrepreneurship - Education], $12,18-35$.

Środa-Murawska, S., Szymańska, D. (2013). The concentration of the creative sector firms as a potential basis for the formation of creative clusters in Poland. Bulletin of Geography. Socio-economic Series, 20(20), 85-93.

Stryjakiewicz, T. (2009). Lokalizacja firm i zachowania przestrzenne pracowników sektora informatycznego (na przykładzie poznańskiego obszaru metropolitalnego). Prace Komisji Geografii Przemystu Polskiego Towarzystwa Geograficznego, 13, 21-33.

Szafrańska, E. (2002). Przemiany struktury funkcjonalnej miast województwa łódzkiego. W: J. Słodczyk (red.), Przemiany bazy ekonomicznej i struktury przestrzennej miast. Opole: Uniwersytet Opolski, 181-192.

Ustawa $z$ dnia 6 marca 2018 r. o Centralnej Ewidencji i Informacji o Działalności Gospodarczej i Punkcie Informacji dla Przedsiębiorcy. Dz.U. 2018, poz. 647. 
Andrzej Raczyk, DSc, University of Wrocław, Institute of Geography and Regional Development, Department of Spatial Management. The author's research interests concern the issues of socio-economic geography, regional policy and cross-border cooperation.

ORCID: https://orcid.org/0000-0002-6400-6087

\section{Adres/Address:}

Uniwersytet Wrocławski

Instytut Geografii i Rozwoju Regionalnego

Zakład Zagospodarowania Przestrzennego

ul. Kuźnicza 49/55

50-138 Wrocław, Polska

e-mail: andrzej.raczyk@uwr.edu.pl 